\title{
· LEGIBILITY
}

A major purpose of the Technical Information Center is to provide the broadest dissemination possible of information contained in DOE's Research and Development Reports to business, industry, the academic community, and federal, state and local governments.

Although a small portion of this report is not reproducible, it is being made available to expedite the availability of information on the research discussed herein. 


\section{HEALTH AND SAFETY RESEARCH DIVISION}

Waste Management Research and Development Programs

(Activity No. AH 100500 0; NEAHO01)

\section{RESULTS OF THE RADICLOGICAL SURVEY AT 133 MAYWOOD AVENUE, MAYWOOD, NEW JEFSEY (MOOE)}

R. D. Foley, R. F. Carrier, L M. Floyd, and J. W. Crutcher

Date Published - October 1989

Investigation Team

R E Swaja - Measurement Applications and Development Manager

W. D. Cottrell - FUSRAP Project Director

R. D. Foley - Field Survey Supervisor

Survey Team Members
A. C. Butler*
P. F. Tiner
M. E Ward•

-D. R. Stone, Aseccintea, Inc

Work performed by the MEASUREMENT APPLICATIONS AND DEVELOPMENT GROUP

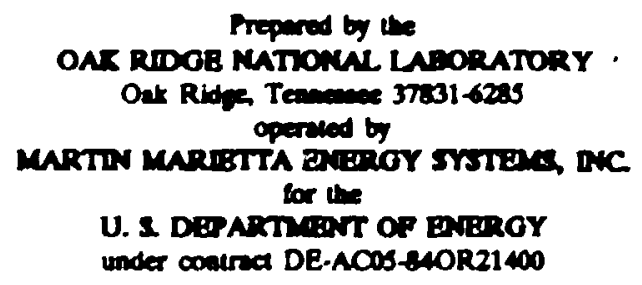




\section{CONTENTS}

LIST OF FIGURES $\ldots \ldots \ldots \ldots \ldots \ldots \ldots \ldots \ldots \ldots$

LIST OF TABLES $\ldots \ldots \ldots \ldots \ldots \ldots \ldots \ldots \ldots$ vii ACKNOWLLDGMENTS $\ldots \ldots \ldots \ldots \ldots \ldots \ldots \ldots$ ix ABSTRACT $\ldots \ldots \ldots \ldots \ldots \ldots \ldots \ldots \ldots \ldots \ldots \ldots \ldots$ INTRODICIION $\ldots \ldots \ldots \ldots \ldots \ldots \ldots \ldots \ldots \ldots \ldots$ SURVEY METHODS $\ldots \ldots \ldots \ldots \ldots \ldots \ldots \ldots \ldots$ SURVEY RESULTS $\ldots \ldots \ldots \ldots \ldots \ldots \ldots \ldots \ldots$

Surface Gamma Radiation Levels $\ldots \ldots \ldots \ldots \ldots \ldots \ldots$

Systematic Soil Samples $\ldots \ldots \ldots \ldots \ldots \ldots \ldots \ldots \ldots$ SIGNIFIC.ANCE OF FINDINGS $\ldots \ldots \ldots \ldots \ldots \ldots \ldots \ldots$ REFERENCES $\ldots \ldots \ldots \ldots \ldots \ldots \ldots \ldots \ldots \ldots \ldots \ldots$ 
LIST OF FIGURES

1 Gamma radiation levels $(\mu R / \mathrm{h})$ measured on the surface at 133 Maywood Avenue, Maywood, New Jersey (MJM25) ....... 5

2 Diagram showing locations of soil samples taken at 133 Maywood Avenue, Maywood, New Jersey (MJ025) . . . . . 6 6

$$
v / r
$$




\section{LIST OF TABLES}

1 Applicable guidelines for protection against radiation $\ldots \ldots \ldots \ldots 7$

2 Background radiation le els for the northern New Jersey

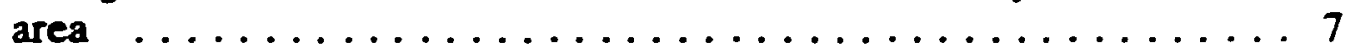

3 Concentrations of selected radionuclides in soil at 133 Maywood Avenue, Maywuod, New Jersey (MJ025) $\ldots \ldots \ldots 8$ 


\section{ACKNOWLEDGMENTS}

Research for this project was sponsored by the U. S. Department of Energy's Division of Facility and Site Decommissioning Projects, under contract DE-ACOS-84OR21400 with Martin Marietta Energy Systems, Inc. The authors wish to acknowledge the support of J. E Baublitz, Acting Director, Office of Remedial Action and Waste Technology; J. J. Fiore, Director, Division of Facility and Site Decommissioning Projects; and members of their staffs. The authors also apprecinte the contributions of D. A Roberts, T. R. Stewart, and P. F. Tiner of the Measurement Applicacions and Development Group; and A. C. Butlet and M. E Ward of D. R. Stone \& Aseociates, Inc., for their participation in the collection, analyses, editing, and reporting of data for this survey. 


\begin{abstract}
Maywood Chemical Worta (MCW) of Maywood, New Jersey, generated process wastes and residues associated with the production and refining of thorium and thorium compounds from monazite ores from 1916 to 1956 MCW supplied rare earth metals and thorium compounds to the Atomic Energy Commiacion and various other government agencies from the late 1940 to the mid-1950. Area residents used the sandlike waste from this thorium extraction process mived with tea and cocon leaves as mulch in their yards. Some of these contaminated wastes were ako eroded from the site into Lodi Brook. At the request of the U.S. Department of Energs (DOE), a group from Oak Ridge National Laboratory conducts investigative radiological surveys of propertics in the vicinity of MCW to determine whether a property is contaminated with radiosetive residues, principally ${ }^{232} \mathrm{Th}$, derived from the MCW site. The surey typically includes direct measurement of gamma radiation levels and soil sampling for radionuclide anatyes. The survey of this site, 133 Maywood Avenue, Maywood, New Jersey (MU025), was conducted during 1987.
\end{abstract}

The survey results demonstrate that all radionuclide concentrations and mearurements conform to DOE remedial action criteria All values are at or below typical background values found in northern New Jersey. 


\section{RESULTS OF THE RADIOLOGICAL SURVEY AT 133 MAYWOOD AVENUE, MAYWOOD, NEW JERSEY (MJ025)*}

\section{INTRODUCTION}

From 1916 to 1956, process wastes and residues associated with the production and refining of thorium and thorium compounds from monazite ores were generated by the Maywood Chemical Worts (MCW), Maywood, New Jersey. During the latter part of this period, MCW supplied rare earth metals and thorium compounds to various government agenciea. In the 1940s and 1950, MCW produced thorium and lithitum, under contract, for the Atomic Energy Comminsion (AEC). These actrities ceased in 1956, and approximately three years later, the 30-acre real estate was purchased by the Stepan Company. The property is beater' at 100 Hunter Avenue in a highty developed area in Maywood and Rochelle Part, Bergen County, New Jersey.

During the earty years of operation, MCW stored wastes and residues in low-lying areas west of the proceasing facilitiea. In the earty 1930, these areas were separated from the rest of the property by the construction of New Jersey State Highway 17. The Stepan property, the interim storage facility, and several vicinity properties have been designated for remedial action by ibe Department of Energy (DOE).

The waste produced by the thorium extraction process was a sandlike material containing residual amounts of thorium and its decay products, with smaller quantities of uranium and its decay products. During the years 1928 and 1944 to 1946, area residents used these process wastes mixed with tea and cocon leaves as mulch in their lawns and gardens. In addition, some of the contaminated wastes were apparently eroded from the site into Lodi Brook and carried downstream.

As a result of the Energy and Water Appropriations Act of Fiscal Year 1984, the property discussed in th's report and properties in its sicinity contaminated with residues from the former $M: \simeq W$, were included as a decontamination research and development project under the DOE Formerly Utilizer Sites Remedial Action Progran. As part of this project, DOE is conducting radiological surveys in the vicinity of the site to identify properties contaminated with residues derived from the MCW. The principal radionuclide of concern is thorium-232. The radiologiral sturvey discused in this report is part of that effort and was conducted, at the request of DOE, by members of the Measurement Applications and Development Group of the Oak Ridge National Laboratory.

-The survey was performed by members of the Measurement Applications and Development group of the Health and Safety Research Division at Oak Ridge National Laboratory under U. S. DOE contract DE-ACO5-84OR21400 with Martin Marietla Energy Systems, Inc. 
A radiological survey of the private property at 133 Maywood Avenue, Maywood, New Jersey, was conducted on April 24, 1987.

\section{SURVEY METHODS}

The radiological survey included a gamma scan of the entire property outdoors, and collection of surface and subsurface soil samples. No indoor survey measurements were performed.

Using a portable gamma sci-itilation meter, ranges of measurements were recorded for areas of the property surface. In addition, systematic soil samples were obtained at randomly sebeted beations irrespective of gamma exposure ratea The survey methods followed the plan outlined in Reference 1. A comprebensive description of the survey methods and instrumentation bas been presented in another report. ${ }^{2}$

\section{SURVEY RESULTS}

Applicalste federal guidelines are summarized in Table $1 .^{3}$ The nomal background radiation levels for the nortbern New Jersey area are presented in Table 2 These data are provided for cumparion with survey results presented in this section. All direct measurement results presented in this report are gross readings; background radiation levels bave not been subtracted. Similatly, background con intrations have not been subtracted from radionuclide concentrations measured in environmental samples.

\section{Surface Gamma Radiation Lovels}

A scan of the surface of the property showed gamma exposure rates ranging from $S$ to $11 \mu \mathrm{R} / \mathrm{h}$ as shown on Fig 1 . No regions of elevated gamma levels were detected.

\section{Syatematic Soil Samples}

Four systematic (S) soil samples were taken from two different locations on the property for radionuclide analyses. Locations of the samples are shown in Fig. 2 with results of laboratory analyses provided in Table 3. Concentrations of radium and thorium in these samples ranged from 0.50 to $0.72 \mathrm{pCi} / \mathrm{g}$ and 0.51 to $0.75 \mathrm{pCi} / \mathrm{g}$ respectively. All sample results were below typical background values encountered in the northern New Jersey area (Table 2). 


\section{SIGNIFICANCE OF FINDINGS}

Surface measurements taken at 133 Maywood Avenue provide evidence that the property contains no radiation levels nor radionuclide concentrations in excess of the typical background values found in northern New Jersey. Based on the results of this radiological assesement, it is recommended that this site be elinisiated from consideration for inclusion in the DOE remedial action program. 


\section{REFERENCES}

1. W. D. Cottrell, ORNL, to A J. Whitman, DOE/HQ, correspondence, "Radiological Survey of Private Properties in Lodi, New Jersey" (August 15, 1984).

2 T. E. Myrick, B. A Berven, W. D. Cottrell, W. A Goldsmith, and F. F. Haywood. Procedures Manual for the ORNL Radiological Survey Activities (RASA) Program, Oak Ridge National Laboratory, ORNLTM-8600 (April 1987).

3. U. S. Department of Energy, Guidelines for Residual Radioactivity at Formerty Utilized Sites, Remedial Action Program and Remole Surplus Facilities Management Program Sites (Rev. 2 March 1987).

4. U. S. Department of Energy, Rodiological Survey of the Middleex Landfill, Middlesex, New Jersey, DOE/EV-00005/20 (April 1980).

5. T. E Myrick and B. A. Berven, State Rackground Radiation Leve's: Rerults of Measurements Taken During 1975-1979, Oak Ridge National Laboratory, ORNLTM-7343 (November 1981). 

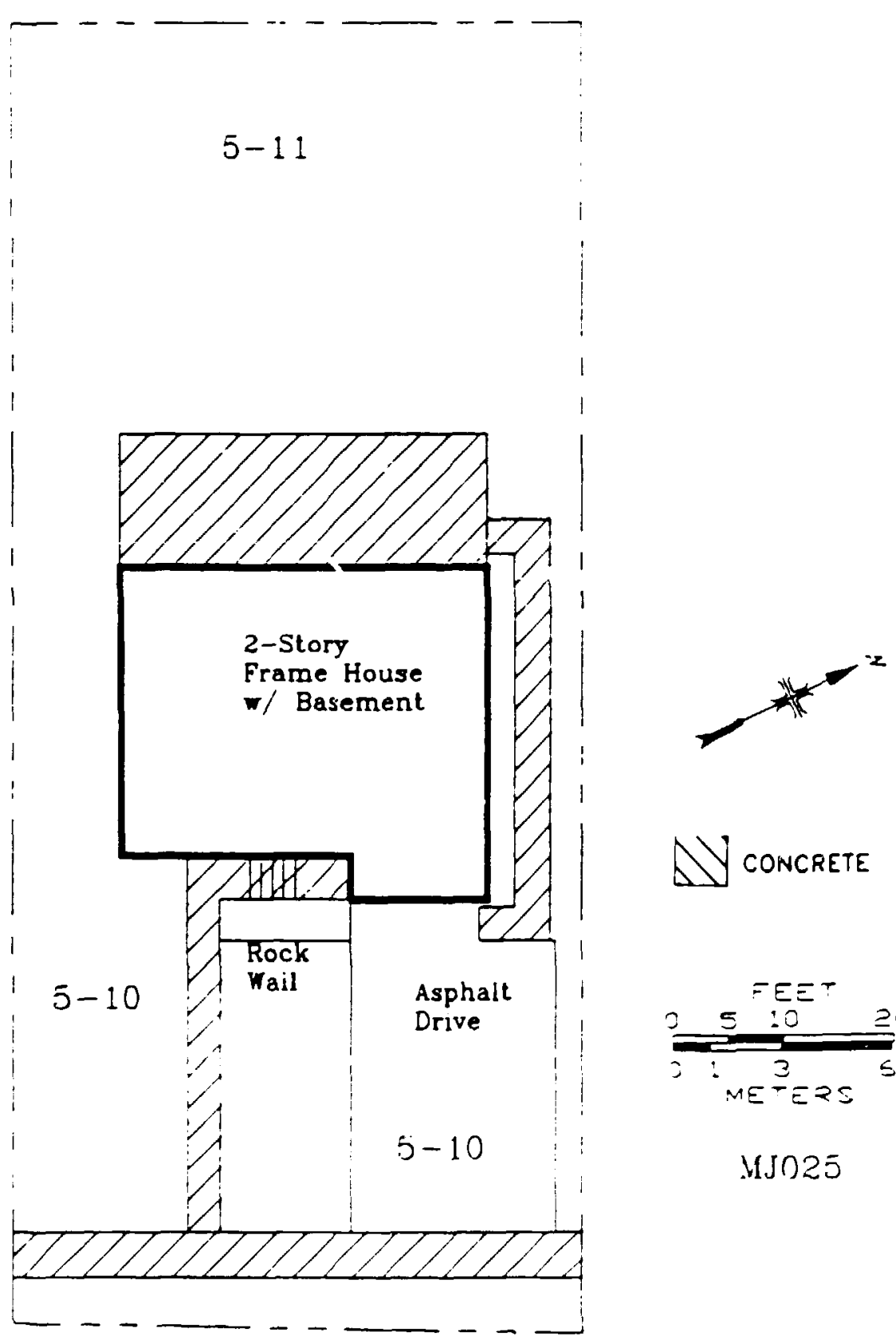

133 Mayroud Avenue

Fig. 1. Gamma radiation levels $(\mu \mathrm{R} / \mathrm{h})$ measured on the surface at $133 \mathrm{iIay}$ wood Avenue, Maywood, New Jersey (MJ025). 
ORNL-DWG 89-14866

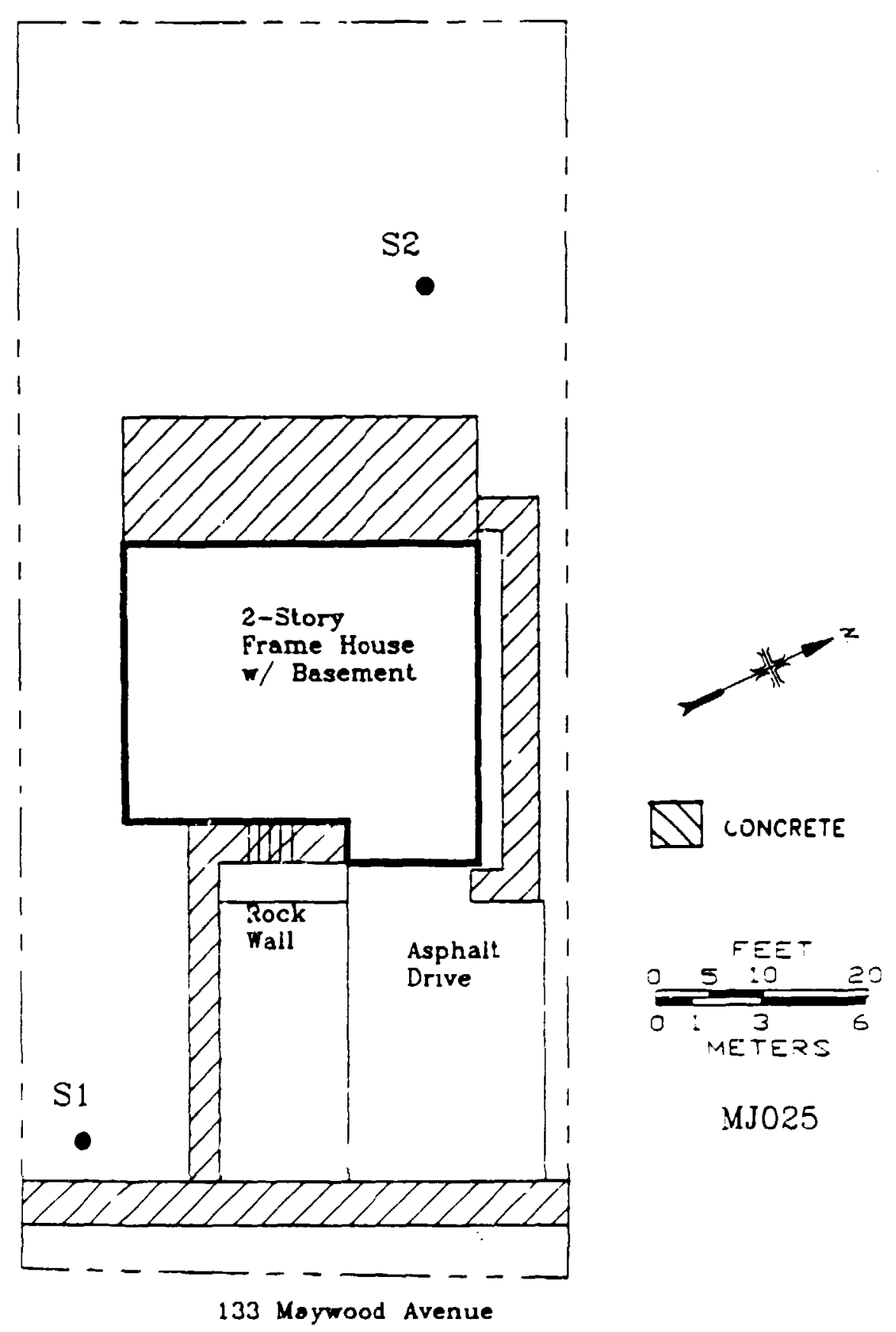

Fig. 2. Diagram showing locations of soil samples taken at 133 Maywood Avenue, Maywood, New Jersey (MJ025). 
Table 1. Applicable guidelines for protection against radiation ${ }^{a}$

Mode of exposure

Radionuclide concentrations in soil
Maximum permissible concentration of the following radionuclides in soil above background levels averaged over a $100 \mathrm{~m}^{2}$ area

$$
\begin{aligned}
& 232 \mathrm{Th} \\
& 220 \mathrm{Th} \\
& 228 \mathrm{Ra} \\
& 226 \mathrm{Ra}
\end{aligned}
$$

Guideline value

$5 \mathrm{pCi} / \mathrm{g}$ averaged over the first $15-\mathrm{cm}$ of soil below the surface; $15 \mathrm{pCi} / \mathrm{g}$ when averaged over 15 $\mathrm{cm}$ thick soil layers more than $15 \mathrm{~cm}$ below the surface

aU. S. Department of Energy, Guidelines for Residual Radioactivity at Formerly Utilized Sites Remedial Action Program and Remote Surplus Facilities Mar agement Program Sites (Rev. 2, March 1987).

Table 2 Background radiation levets for the northern New Jersey area

\begin{tabular}{lc}
\hline $\begin{array}{c}\text { Type of sample } \\
\text { or measurement }\end{array}$ & $\begin{array}{c}\text { Radionuclide level or } \\
\text { radionuclide concentration }\end{array}$ \\
\hline $\begin{array}{l}\text { Gamma cxposure rate at } 1 \mathrm{~m} \text { above } \\
\text { ground surface }(\mu \mathrm{R} / \mathrm{h}) \boldsymbol{a}\end{array}$ & 8 \\
Concentration of radionuclides & \\
in soil $(\mathrm{pCi} / \mathrm{g})^{b}$ & \\
$232 \mathrm{Th}$ & 0.9 \\
$238_{\mathrm{U}}$ & 0.9 \\
226 & 0.9 \\
\hline
\end{tabular}

aReference 4.

${ }^{b}$ Reference 5. 
Table 3. Concentrations of radionuclides in soil at 133 Maywood Avenue, Maywood, New Jersey (MJ025)

\begin{tabular}{llll} 
Sample & $\begin{array}{c}\text { Depth } \\
(\mathrm{cm})\end{array}$ & $\frac{\text { Radionuclide concentration }(\mathrm{pCi} / \mathrm{g})}{{ }^{226} \mathrm{Ra}^{6}}$ & ${ }^{232} \mathrm{Th}^{b}$ \\
\hline
\end{tabular}

Systematic samples

$\begin{array}{lrll}\text { S1A } & 0-15 & 0.72 \pm 0.02 & 0.75 \pm 0.03 \\ \text { S1B } & 15-30 & 0.50 \pm 0.06 & 0.62 \pm 0.09 \\ \text { S2A } & 0-15 & 0.71 \pm 0.05 & 0.62 \pm 0.2 \\ \text { S2B } & 15-30 & 0.52 \pm 0.04 & 0.51 \pm 0.06\end{array}$

- Locations of soil samples are shown on Fig. 2.

'Indicated counting error is at the $95 \%$ confidence level $( \pm 2 \sigma)$. 